\title{
Lost verplichte aanwijzing accountant problemen van beursvennootschappen op?
}

\author{
$M r . d r . E . V . A$. Eijkelenboom*
}

\begin{abstract}
Controleplichtig maar geen accountant kunnen vinden. Het overkomt verschillende beursvennootschappen. Minister Hoekstra is daarom voornemens om een verplichte toewijzing van een accountant aan controleplichtige entiteiten wettelijk te verankeren. In deze bijdrage staan de achtergrond en enkele aandachtspunten bij het voornemen van verplichte aanwijzing van de accountant centraal.
\end{abstract}

\section{Inleiding}

'Wetswijziging moet accountants dwingen tot controle beursfondsen', kopte Het Financieele Dagblad op 8 juli 2020 net voor aanvang van het zomerreces in Den Haag. ${ }^{1}$

Voor de bekenden in de accountantswereld komt het voornemen tot een wetswijziging niet als een verrassing. De precieze vorm en inhoud van het voornemen zijn nog onbekend. Naast het voornemen tot aanwijzing van de accountant sprak minister Hoekstra zich in maart dit jaar in reactie op de uitkomsten van het onderzoek van de Commissie Toekomst Accountancysector (CTA) positief uit over diverse wetswijzigingen. ${ }^{2} \mathrm{Zo}$ noemde hij onder meer de mogelijkheid van het wettelijk vastleggen van audit quality indicators om het inzicht in verbeterpunten binnen de accountantsorganisaties te vergroten, het (verder) uitbreiden van bevoegdheden van het interne toezichtsorgaan van de accountantsorganisatie en het benoemen van een kwartiermaker die voortvarend de uitvoering van de aanbevelingen van de CTA ter hand neemt. ${ }^{3}$ Vooruitlopend op het 'algemeen overleg accountancy' stelde minister Hoekstra Marlies de Vries en Chris Fonteijn als kwartiermakers aan om tot december 2023 de voortgang van de uitvoering van de CTA-aanbevelingen in de accountantssector te borgen. ${ }^{4}$

\footnotetext{
Mr. dr. E.V.A. Eijkelenboom werkt bij VNO-NCW | MKB-Nederland, is verbonden aan de Erasmus Universiteit Rotterdam en lid van de redactie van dit tijdschrift.

Zij schrijft deze bijdrage op persoonlijke titel.

1. R. Baurichter \& S. Motké, Wetswijziging moet accountants dwingen tot controle beursfondsen, Het Financieele Dagblad 8 juli 2020, p. 1 en 3.

2. Zie voor een achtergrond en voorlopige bevindingen van de CTA het artikel van J.B.S. Hijink \& L. in 't Veld, Voorlopige bevindingen Commissie Toekomst Accountancysector, Ondernemingsrecht 2020/17.

3. Kamerstukken II 2019/20, 33977, nr. 29.

4. Zie Kamerstukken II 2019/20, 33977, nr. 31 en het Instellingsbesluit Kwartiermakers toekomst accountancysector.
}

Het voornemen van de toewijzing van de accountant haalde echter recent de krant, nadat verschillende beursvennootschappen - dat wil zeggen rechtspersonen waarvan de effecten zijn toegelaten tot de handel op een gereglementeerde markt, zoals Euronext Amsterdam - melding makkten geen accountant te kunnen vinden die hun jaarcijfers controleert. Dat sommige beursvennootschappen geen accountant kunnen vinden, is overigens geen nieuw fenomeen. Eerder kwamen onder meer Lavide Holding N.V., Esperite N.V. en Value8 N.V. al in het nieuws door hun zoektocht naar een accountant. $^{5}$ De CTA betrok mede daarom ook het niveau van concurrentie in de accountancysector in haar onderzoek. ${ }^{6}$

\section{Ontbrekende controleverklaring: een punt van aandacht}

Beursvennootschappen zijn wettelijk verplicht binnen vier maanden na afronding van het boekjaar hun jaarlijkse financiële verslaggeving algemeen verkrijgbaar te stellen (art. 5:25c $\mathrm{Wft}$ ). Onderdeel van de jaarlijkse financiële verslaggeving is de accountantsverklaring. In Nederland zijn er momenteel zes accountantsorganisaties die een vergunning hebben om beursvennootschappen te controleren. ${ }^{7}$ Beursvennootschappen kwalificeren als 'organisatie van openbaar belang' (OOB). ${ }^{8}$ Om OOB's te mogen controleren hebben accountantsorganisaties een OOB-vergunning nodig. ${ }^{9}$ Dat slechts een beperkt aantal accountantsorganisaties een OOB-vergunning heeft, is volgens de onderzoeksbevindingen van de CTA geen probleem. Hoewel het aantal OOB-accountantsorganisaties

5. Zie L. in 't Veld, Druk of vacuüm? Externe accountant voor Lavide gezocht, Ondernemingsrecht 2018/110; Accountancy Vanmorgen, Biotechbedrijf Esperite kan geen accountant vinden, 21 februari 2020, geraadpleegd op accountancyvanmorgen.nl; redactie Accountant.nl, Value8 wil boekjaar verlengen als het geen accountant vindt, 18 november 2019, geraadpleegd op accountant.nl.

6. Kamerstukken II 2019/20, 33977, nr. 28 (bijlage 1: Vertrouwen op controle. Rapport van de Commissie toekomst accountancysector), hoofdstuk 6.

7. Zie voor de OOB-accountantsorganisaties het 'register accountantsorganisaties' op afm.nl. De zes accountantsorganisaties met OOB-vergunning zijn BDO Audit \& Assurance B.V., Deloitte Accountants B.V., Ernst \& Young Accountants LLP, KPMG Accountants N.V., Mazars Accountants N.V. en PricewaterhouseCoopers Accountants N.V.

8. Art. 1 lid 1 sub $1 \mathrm{Wta}$.

9. Art. 6 lid $2 \mathrm{Wta}$. 
beperkt is en afneemt, is er volgens de CTA vooralsnog voldoende concurrentie op de markt. ${ }^{10} \mathrm{Wel}$ is het een punt van aandacht dat niet elke beursvennootschap een accountant kan vinden.

Een jaarrekening zonder accountantsverklaring heeft verstrekkende gevolgen voor de beursvennootschap, omdat dan de jaarrekening niet vastgesteld kan worden (art. 2:393 lid 7 $\mathrm{BW}$ ), waardoor bijvoorbeeld geen dividend kan worden uitgekeerd (art. 2:105 lid 3/2:216 lid $1 \mathrm{BW}$ ). Tevens kwalificeert het ontbreken van een controle als een economisch delict (art. 1 sub 4 WED). Daarnaast kan beurshuis Euronext maatregelen nemen bij het ontbreken van een accountantsverklaring bij de jaarrekening van de beursvennootschap. Dit is recent ook gebeurd, waardoor het voor de beursvennootschap bijvoorbeeld lastiger wordt om kapitaal aan te trekken. ${ }^{11}$

Ook het maatschappelijk verkeer, de gebruiker van de jaarrekening, is gebaat bij de informatie uit de accountantsverklaring, die vertrouwen toevoegt aan de cijfers uit de jaarrekening. Het ontbreken van de accountantsverklaring kan dan ook leiden tot maatschappelijke onrust, met een koersreactie als gevolg. Het niet kunnen vinden van de accountant in Nederland kan beursvennootschappen bovendien prikkelen om Euronext te verlaten en hun heil in het buitenland te zoeken. De CTA merkt de situatie dat beursfondsen geen accountant kunnen vinden dan ook terecht als 'onwenselijk' aan. ${ }^{12}$ Als oplossing voor deze situatie doet de CTA de aanbeveling om de minister de bevoegdheid te geven om een accountant toe te wijzen aan een organisatie die geen accountant kan vinden. ${ }^{13}$ Een aanbeveling die de minister, blijkens de kabinetsreactie, overneemt. ${ }^{14} \mathrm{Hij}$ wil die bevoegdheid overigens niet beperken tot beursvennootschappen, maar breder inzetten voor alle entiteiten - niet enkel OOB's - die belast zijn met een wettelijk verplichte controle.

\section{Gevolgen van verplichte aanwijzing accountant onduidelijk}

Een aanwijzingsbevoegdheid is een verstrekkende bevoegdheid in een open economie. Het staat marktpartijen tenslotte vrij om zelfstandig keuzes te maken met wie zij wel én met wie zij niet contracteren. Er kunnen goede redenen bestaan voor accountantsorganisaties om een opdracht te weigeren. Zo wij-

10. In 2010 waren er vijftien OOB-accountantsorganisaties. Redenen voor afname zijn bijv. het intrekken van de vergunning op aandringen van de AFM of het intrekken van de vergunning doordat de OOB-accountantsorganisatie geen of weinig OOB's controleerde. AFM, Sector in beeld. Marktanalyse accountantsorganisaties 2010-2014, 14 september 2015, geraadpleegd op www.afm.nl. Kamerstukken II 2019/20, 33977, nr. 28 (bijlage 1: Vertrouwen op controle. Rapport van de Commissie toekomst accountancysector), par. 319-321.

11. Baurichter \& Motké 2020, p. 1.

12. Kamerstukken II 2019/20, 33977, nr. 28 (bijlage 1: Vertrouwen op controle. Rapport van de Commissie toekomst accountancysector), aanhef p. 83.

13. Kamerstukken II 2019/20, 33977, nr. 28 (bijlage 1: Vertrouwen op controle. Rapport van de Commissie toekomst accountancysector), par. 341.

14. Kamerstukken II 2019/20, 33977, nr. 29, p. 13. zen controleurs en gebruikers van jaarlijkse financiële verslaggeving bijvoorbeeld op het ontbreken van kwaliteitsvoorwaarden als interne beheersing en integere bedrijfsvoering binnen de beursvennootschap. Ook kunnen er belangenconflicten bestaan die een weigering van de opdracht door de accountant rechtvaardigen. ${ }^{15}$ Ten slotte zorgt ook de voor OOB-accountantsorganisaties geldende onafhankelijkheidsregelgeving (met afkoelingsperiode) voor een beperking van het aanbod van beschikbare accountantsorganisaties. ${ }^{16}$ Kortom, het voornemen tot verplichte toewijzing van een accountant lijkt voor beursvennootschappen die geen accountant kunnen vinden een gelukkige greep.

Of toewijzing van een accountant aan een beursvennootschap daadwerkelijk positieve gevolgen voor de beursvennootschap heeft, is echter de vraag. Alvorens die vraag te kunnen beantwoorden, is in ieder geval meer kennis nodig over de werking van het toewijzingsmechanisme en de gevolgen van verplichte aanwijzing voor de kosten van de controle en de aansprakelijkheid van partijen.

\section{Enkele aandachtspunten bij verplichte aanwijzing accountant}

Op grond van artikel 2:393 lid $1 \mathrm{BW}$ verleent de rechtspersoon opdracht tot onderzoek van de jaarrekening aan de accountant. De algemene vergadering is tot het verlenen van de opdracht bevoegd en bij ontbreken (of in gebreke blijven) van de algemene vergadering kan de raad van commissarissen $(\mathrm{RvC})$ tot opdrachtverlening overgaan (art. 2:393 lid $2 \mathrm{BW}$ ). In geval van gegronde redenen kan de opdracht worden ingetrokken door de algemene vergadering en door degene die haar heeft verleend. Indien sprake is van verplichte aanwijzing van de accountant in de situatie dat de opdrachtverlening aan de accountant door de $\mathrm{RvC}$ zou zijn gedaan, verliest de $\mathrm{RvC}$ de bevoegdheid tot intrekken van de opdracht in geval van gegronde redenen. ${ }^{17}$ Verplichte toewijzing verzwakt daardoor de governance van de vennootschap en daarmee de positie van de vennootschap ten opzichte van de accountant. Deze situatie zal zich in de praktijk bij beursvennootschappen naar verwachting niet voordoen. Toch is dit wel degelijk een punt van aandacht, nu de minister overweegt de toewijzing in te zetten voor alle entiteiten die belast zijn met een wettelijk verplichte controle. $^{18}$

De minister geeft aan te gaan onderzoeken welke entiteit het beste gepositioneerd is voor aanwijzing van de accountant en

15. Kamerstukken II 2019/20, 33977, nr. 28 (bijlage 1: Vertrouwen op controle. Rapport van de Commissie toekomst accountancysector), par. 342-345.

16. Zie art. 17 Verordening (EU) 537/2014 van het Europees Parlement en de Raad van 16 april 2014 betreffende specifieke eisen voor de wettelijke controles van financiële overzichten van organisaties van openbaar belang en tot intrekking van Besluit 2005/909/EG van de Commissie, PbEU 2014, L 158/77; art. 23 en $24 b$ Wta.

17. De aandeelhouders kunnen de opdracht nog wel intrekken in geval van gegronde redenen op grond van art. 2:393 lid $2 \mathrm{BW}$.

18. Kamerstukken II 2019/20, 33977, nr. 29, p. 13. 
wat de eventuele juridische consequenties zijn. ${ }^{19}$ Als voorbeeld noemt de minister de Nederlandse Beroepsorganisatie van Accountants (NBA). Er zijn echter ook andere mogelijkheden denkbaar. Zo noemt accountantsorganisatie EY in reactie op dit voornemen de mogelijkheid om de toewijzingsbevoegdheid bij het Ministerie van Financiën te beleggen in samenspraak met toezichthouder AFM en accountantsorganisaties. Accountantsorganisatie Mazars noemt als alternatief een 'intermediairscommissie', 'waarbij de toezichthouder op de betreffende kapitaalmarkt samen met de NBA in voorkomende gevallen samen de weigeringen beoordeelt en daar zo nodig een bemiddelende rol in speelt'. ${ }^{20}$

Nadeel van voorgaande alternatieven is dat de aansprakelijkheidsrisico's mogelijk vergroten. In geval van een faillissement van een vennootschap waar de accountant is aangewezen, bestaat het risico dat naast de accountant ook de aanwijzende partij aansprakelijk wordt gesteld door de curatoren in geval van vermoedens van onzorgvuldigheid bij aftekenen. Een ander nadeel is dat de opdracht uiteindelijk wordt verleend aan een OOB-accountantsorganisatie die in eerste instantie weigerde de opdracht te aanvaarden. Indien de OOBaccountantsorganisatie weigerde in verband met tekortschietende capaciteit kan verplichte toewijzing leiden tot hogere werkdruk binnen de accountantsorganisatie, met mogelijke kwaliteitsproblemen als gevolg. Verplichte toewijzing kan er ook toe leiden dat de OOB-accountantsorganisatie een risico moet nemen dat zij oorspronkelijk niet bereid was te nemen. Dat kan leiden tot aanvullende werkzaamheden (en hogere kosten) of ten koste gaan van de kwaliteit. Overigens zou 'risk pooling' - het gezamenlijk dragen van risico's, kosten en opbrengsten - voor accountantsorganisaties mogelijk kunnen helpen om de verhoogde risico's bij verplichte toewijzing te kunnen dragen. Die samenwerkingsgedachte vereist wel nader onderzoek om te borgen dat mededingings- en onafhankelijkheidsregels niet worden overtreden.

Er zijn ook andere toewijzingsconstructies denkbaar. Zo wijst EY op de mogelijkheid van het oprichten van een stichting 'die zich uitsluitend richt op het controleren van ondernemingen die geen accountant kunnen vinden'. ${ }^{21}$ Wellicht een meer voor de hand liggende oplossing - die naar mijn weten vooralsnog ontbreekt in het publieke debat - is het alternatief om beursvennootschappen zonder accountant toe te wijzen aan de Rijksaccountantsdienst. Dit heeft niet alleen als voordeel dat het een al bestaande dienst betreft, maar ook dat de aansprakelijkheidsrisico's die gepaard gaan met het verplicht toewijzen in het publiek belang gedragen worden door de overheid, en dus niet ten laste komen van een kleine groep OOB-accountantsorganisaties. Tegelijk vergt deze oplossingsrichting wel aandacht voor geheimhoudingsplichten en de

19. Kamerstukken II 2019/20, 33977, nr. 29, p. 13.

20. B. Remmerswaal, OOB-kantoren: 'Aanwijzingsbevoegdheid niet los te zien van acceptatievoorwaarden', 17 juli 2020, geraadpleegd op accountant.nl.

21. Remmerswaal 2020. bescherming van de informatie van de controleplichtige entiteiten.

Of de verplichte toewijzing van de accountant leidt tot meer inzicht voor het maatschappelijk verkeer dan zonder accountantsverklaring het geval is, is echter onzeker. Zo bestaat er voor de accountant de mogelijkheid om een verklaring van oordeelonthouding te geven (art. 2:393 lid 6 sub d BW). Het maatschappelijk verkeer verkrijgt met een verklaring van oordeelonthouding geen inhoudelijk oordeel over de jaarrekening, terwijl de kosten voor de controle ten minste net zo hoog en wellicht zelfs hoger uitvallen. Immers, ook om een verklaring van oordeelonthouding te kunnen geven is het noodzakelijk dat de accountant werkzaamheden verricht en vaststelt dat geen voldoende en geschikte controle-informatie kan worden gekregen. ${ }^{22}$

\section{Tot besluit}

Voorgaande selectie van aandachtspunten makt inzichtelijk dat er nog veel onduidelijkheden bestaan over de gevolgen van het voornemen tot verplichte aanwijzing van de accountant. Inzicht in de eventuele veranderingen van bevoegdheden, aansprakelijkheden en kosten ontbreekt vooralsnog voor partijen die betrokken zijn bij de totstandkoming van de jaarlijkse financiële verslaggeving. Dat vereist onderzoekswerk met aandacht voor de verschillende belangen en juridische gevolgen, met als resultaat: doordachte wetgeving waarin maatschappelijke baten opwegen tegen de kosten.

22. Standaard 705 van de Nadere voorschriften controle- en overige standaarden (NV COS). 